\title{
PROGRAM KEMITRAAN MASYARAKAT (PKM) MOTIVASI KERJA TERHADAP PRESTASI KERJA PEGAWAI PADA DINAS KEPEMUDAAN DAN OLAHRAGA KOTA TOMOHON
}

\author{
Jetje Fonny Sumampouw \\ Universitas Negeri Manado \\ jetjesumampouw@unima.ac.id
}

\begin{abstract}
Abstrak
Adapun tujuan Program Kemitraan Masyarakat ini adalah: 1). Menemukan apa saja yang mempengaruhi Prestasi Kerja Pegawai Dinas Kepemudaan dan Olahraga Kota Tomohon; 2). Meningkatkan motivasi kerja pegawai di Dinas Kepemudaan dan Olahraga Kota Tomohon. Program Kemitraan Ini bertempat di Dinas Kepemudaan dan Olahraga Kota Tomohon, menggunakan metode Focus Group Disccusion dan menghasilkan, Pegawai pada Dinas Kepemudaan dan Olahraga Kota Tomohon, cenderung memilih variabel Kebutuhan Sosial yang paling menyentuh dan memotivasi semangat bekerja mereka, karena merupakan dorongan yang sangat berarti apabila karayawan bekerja dengan kondisi kerja yang baik karena interaksi sosial sesama pegawai bahkan dengan atasan berjalan dengan baik, dan itu dirasakan besar sekali pengaruhnya buat diri pegawai.
\end{abstract}

Kata kunci: Prestasi Kerja, Variabel, Dinas Kepemudaan

\section{PENDAHULUAN}

\section{Analisis Situasi}

Sumber daya manusia didalam organisasi merupakan hal yang sangat menentukan berhasil tidaknya suatu organisasi dalam mencapai tujuan yang telah ditetapkan. Organisasi harus memacu motivasi kerja karyawannya, mengingat pentingnya peran sumber daya manusia dalam organisasi itu sendiri. Setiawan dan Ghozali menyatakan bahwa kinerja merupakan fungsi dari motivasi dan kemampuan (kompetensi) kerja pegawai [1]. Selanjutnya Setiawan dan Gozali menyatakan bahwa kemampuan (kompetensi) adalah bakat individu untuk melaksanakan suatu tugas yang berhubungan dengan tujuan. Motivasi kerja saja tidak cukup untuk meningkatkan kinerja jika individu yang bersangkutan tidak memiliki kompetensi berupa keterampilan dan pengetahuan yang dibutuhkan untuk melaksanakan suatu pekerjaan. Vroom dalam Hailesilasie, menyatakan bahwa ketika seorang pegawai memiliki kemampuan kerja yang rendah, peningkatan motivasi hanya akan menghasilkan peningkatan kinerja yang rendah dibandingkan jika pegawai memiliki kemampuan kerja yang tinggi [2].

Prestasi kerja yang dilakukan oleh pegawai perlu penilaian. Prestasi kerja sangat penting dalam perjalanan karir pegawai. Penilaian prestasi kerja yang rasional dan diterapkan secara objektif terikat pada dua kepentingan, yaitu kepentingan pegawai dan kepentingan organisasi. Prestasi kerja juga penting untuk aktualisasi diri. Pegawai yang tidak mempunyai prestasi kerja tidak akan 
pernah mencapai kematangan psikologis dan pada gilirannya akan frustasi. Sedangkan pegawai yang mempunyai prestasi kerja biasanya mempunyai catatan kehadiran yang lebih baik daripada pegawai yang tidak mempunyai prestasi kerja. Oleh karena itu prestasi kerja mempunyai arti penting baik bagi pegawai maupun organisasi, terutama karena menciptakan keadaan positif di dalam lingkungan perusahaan atau organisasi.

Prestasi kerja yang dilakukan oleh pegawai perlu penilaian. Prestasi kerja sangat penting dalam perjalanan karir pegawai. Penilaian prestasi kerja yang rasional dan diterapkan secara objektif terikat pada dua kepentingan, yaitu kepentingan pegawai dan kepentingan organisasi. Prestasi kerja juga penting untuk aktualisasi diri. Pegawai yang tidak mempunyai prestasi kerja tidak akan pernah mencapai kematangan psikologis dan pada gilirannya akan frustasi. Sedangkan pegawai yang mempunyai prestasi kerja biasanya mempunyai catatan kehadiran yang lebih baik daripada pegawai yang tidak mempunyai prestasi kerja. Oleh karena itu prestasi kerja mempunyai arti penting baik bagi pegawai maupun organisasi, terutama karena menciptakan keadaan positif di dalam lingkungan perusahaan atau organisasi.

Prestasi kerja yang dilakukan oleh pegawai perlu penilaian. Prestasi kerja sangat penting dalam perjalanan karir pegawai. Penilaian prestasi kerja yang rasional dan diterapkan secara objektif terikat pada dua kepentingan, yaitu kepentingan pegawai dan kepentingan organisasi. Prestasi kerja juga penting untuk aktualisasi diri. Pegawai yang tidak mempunyai prestasi kerja tidak akan pernah mencapai kematangan psikologis dan pada gilirannya akan frustasi. Sedangkan pegawai yang mempunyai prestasi kerja biasanya mempunyai catatan kehadiran yang lebih baik daripada pegawai yang tidak mempunyai prestasi kerja. Oleh karena itu prestasi kerja mempunyai arti penting baik bagi pegawai maupun organisasi, terutama karena menciptakan keadaan positif di dalam lingkungan perusahaan atau organisasi. Prestasi kerja yang dilakukan oleh pegawai perlu penilaian. Prestasi kerja sangat penting dalam perjalanan karir pegawai. Penilaian prestasi kerja yang rasional dan diterapkan secara objektif terikat pada dua kepentingan, yaitu kepentingan pegawai dan kepentingan organisasi. Prestasi kerja juga penting untuk aktualisasi diri. Pegawai yang tidak mempunyai prestasi kerja tidak akan pernah mencapai kematangan psikologis dan pada gilirannya akan frustasi. Sedangkan pegawai yang mempunyai prestasi kerja biasanya mempunyai catatan kehadiran yang lebih baik daripada pegawai yang tidak mempunyai prestasi kerja. Oleh karena itu prestasi kerja mempunyai arti penting baik bagi pegawai maupun organisasi, terutama karena menciptakan keadaan positif di dalam lingkungan perusahaan atau organisasi. 
Prestasi kerja yang dilakukan oleh pegawai perlu penilaian. Prestasi kerja sangat penting dalam perjalanan karir pegawai. Penilaian prestasi kerja yang rasional dan diterapkan secara objektif terikat pada dua kepentingan, yaitu kepentingan pegawai dan kepentingan organisasi. Prestasi kerja juga penting untuk aktualisasi diri. Pegawai yang tidak mempunyai prestasi kerja tidak akan pernah mencapai kematangan psikologis dan pada gilirannya akan frustasi. Sedangkan pegawai yang mempunyai prestasi kerja biasanya mempunyai catatan kehadiran yang lebih baik daripada pegawai yang tidak mempunyai prestasi kerja. Oleh karena itu prestasi kerja mempunyai arti penting baik bagi pegawai maupun organisasi, terutama karena menciptakan keadaan positif di dalam lingkungan perusahaan atau organisasi. Prestasi kerja yang dilakukan oleh pegawai perlu penilaian. Prestasi kerja sangat penting dalam perjalanan karir pegawai. Penilaian prestasi kerja yang rasional dan diterapkan secara objektif terikat pada dua kepentingan, yaitu kepentingan pegawai dan kepentingan organisasi. Prestasi kerja juga penting untuk aktualisasi diri. Pegawai yang tidak mempunyai prestasi kerja tidak akan pernah mencapai kematangan psikologis dan pada gilirannya akan frustasi. Sedangkan pegawai yang mempunyai prestasi kerja biasanya mempunyai catatan kehadiran yang lebih baik daripada pegawai yang tidak mempunyai prestasi kerja. Oleh karena itu prestasi kerja mempunyai arti penting baik bagi pegawai maupun organisasi, terutama karena menciptakan keadaan positif di dalam lingkungan perusahaan atau organisasi.

\section{Permasalahan Mitra}

Dari hasil analisis diatas maka permasalahan mitrayang ditemui adalah bahwa, masih kurangnya motivasi pegawai terhadap prestasi kerja di Dinas Kepemudaan dan Olahraga Kota Tomohon

\section{SOLUSI DAN TARGET LUARAN}

\section{Target Luaran}

1. Menemukan apa saja yang mempengaruhi Prestasi Kerja Pegawai Dinas Kepemudaan dan Olahraga Kota Tomohon

2. Meningkatkan motivasi kerja pegawai di Dinas Kepemudaan dan Olahraga Kota Tomohon

\section{Solusi yang di tawarkan}

1. Melakukan focus group discussion untuk menemukan apa saja yang mempengaruhi prestasi kerja pegawai Dinas Kepemudaan dan Olahraga Kota Tomohon

\section{METODE PELAKSANAAN}

Metode yang digunakan adalah Focus Group Discussion

Sesuai namanya, pengertian Focus Group Discussion mengandung tiga kata kunci: a. Diskusi (bukan wawancara atau obrolan);

b. Kelompok (bukan individual); 
c. Terfokus/Terarah (bukan bebas). Artinya, walaupun hakikatnya adalah sebuah diskusi, FGD tidak sama dengan wawancara, rapat, atau obrolan beberapa orang di kafe-kafe. FGD bukan pula sekadar kumpul-kumpul beberapa orang untuk membicarakan suatu hal. Banyak orang berpendapat bahwa FGD dilakukan untuk mencari solusi atau menyelesaikan masalah. Artinya, diskusi yang dilakukan ditujukan untuk mencapai kesepakatan tertentu mengenai suatu permasalahan yang dihadapi oleh para peserta, padahal aktivitas tersebut bukanlah FGD, melainkan rapat biasa. FGD berbeda dengan arena yang semata-mata digelar untuk mencari konsensus.

Sebagai alat penelitian, FGD dapat digunakan sebagai metode primer maupun sekunder. FGD berfungsi sebagai metode primer jika digunakan sebagai satu-satunya metode penelitian atau metode utama (selain metode lainnya) pengumpulan data dalam suatu penelitian. FGD sebagai metode penelitian sekunder umumnya digunakan untuk melengkapi riset yang bersifat kuantitatif dan atau sebagai salah satu teknik triangulasi. Di luar fungsinya sebagai metode penelitian ilmiah, Krueger \& Casey menyebutkan, FGD pada dasarnya juga dapat digunakan dalam berbagai ranah dan tujuan, misalnya (1) pengambilan keputusan, (2) needs assesment, (3) pengembangan produk atau program, (4) mengetahui kepuasan pelanggan, dan sebagainya [3].

\section{Persiapan dan Desain Rancangan FGD}

Sebagai sebuah metode penelitian, pelaksanaan FGD memerlukan perencanaan matang dan tidak asal-asalan. Untuk diperlukan beberapa persiapan sebagai berikut: 1) Membentuk Tim; 2) Memilih Tempat dan Mengatur Tempat; 3) Menyiapkan Logistik; 4 Menentukan Jumlah Peserta; dan 5) Rekruitmen Peserta.

1) Membentuk Tim

Tim FGD umumnya mencakup:

1. Moderator, yaitu fasilitator diskusi yang terlatih dan memahami masalah yang dibahas serta tujuan penelitian yang hendak dicapai (ketrampilan substantif), serta terampil mengelola diskusi (ketrampilan proses).

2. Asisten Moderator/co-fasilitator, yaitu orang yang intensif mengamati jalannya FGD, dan ia membantu moderator mengenai: waktu, fokus diskusi (apakah tetap terarah atau keluar jalur), apakah masih ada pertanyaan penelitian yang belum terjawab, apakah ada peserta FGD yang terlalu pasif sehingga belum memperoleh kesempatan berpendapat.

3. Pencatat Proses/Notulen, yaitu orang bertugas mencatat inti permasalahan yang didiskusikan serta dinamika kelompoknya. Umumnya dibantu dengan alat pencatatan berupa satu unit komputer atau laptop yang lebih fleksibel.

4. Penghubung Peserta, yaitu orang yang mengenal (person, medan), menghubungi, dan memastikan partisipasi peserta. Biasanya disebut mitra kerja lokal di daerah penelitian. 
5. Penyedia Logistik, yaitu orang-orang yang membantu kelancaran FGD berkaitan dengan penyediaan transportasi, kebutuhan rehat, konsumsi, akomodasi (jika diperlukan), insentif (bisa uang atau barang/cinderamata), alat dokumentasi, dll.

6. Dokumentasi, yaitu orang yang mendokumentasikan kegiatan dan dokumen FGD: memotret, merekam (audio/video), dan menjamin berjalannya alat-alat dokumentasi, terutama perekam selama dan sesudah FGD berlangsung.

7. Lain-lain jika diperlukan (tentatif), misalnya petugas antar-jemput, konsumsi, bloker (penjaga "keamanan" FGD, dari gangguan, misalnya anak kecil, preman, telepon yang selalu berdering, teman yang dibawa peserta, atasan yang datang mengawasi, dsb)

\section{2) Memilih dan Mengatur Tempat}

Pada prinsipnya, FGD dapat dilakukan di mana saja, namun seyogianya tempat FGD yang dipilih hendaknya merupakan tempat yang netral, nyaman, aman, tidak bising, berventilasi cukup, dan bebas dari gangguan yang diperkirakan bisa muncul (preman, pengamen, anak kecil, dsb). Selain itu tempat FGD juga harus memiliki ruang dan tempat duduk yang memadai (bisa lantai atau kursi). Posisi duduk peserta harus setengah atau tiga perempat lingkaran dengan posisi moderator sebagai fokusnya. Jika FGD dilakukan di sebuah ruang yang terdapat pintu masuk yang depannya ramai dilalui orang, maka hanya moderator yang boleh menghadap pintu tersebut, sehingga peserta tidak akan terganggu oleh berbagai "pemandangan" yang dapat dilihat diluar rumah.

Jika digambarkan, layout ruang diskusi dapat dilihat pada gambar di atas.

3) Menyiapkan Logistik

Logistik adalah berbagai keperluan teknis yang dipelukan sebelum, selama, dan sesudah FGD terselenggara. Umumnya meliputi peralatan tulis (ATK), dokumentasi (audio/video), dan kebutuhan-kebutuhan peserta FGD: seperti transportasi; properti rehat: alat ibadah, konsumsi (makanan kecil dan atau makan utama); insentif; akomodasi (jika diperlukan); dan lain sebagainya.

Insentif dalam penyelenggaraan FGD adalah suatu hal yang wajar diberikan. Selain sebagai strategi untuk menarik minat peserta, pemberian insentif juga merupakan bentuk ungkapan terimakasih peneliti karena peserta FGD bersedia meluangkan waktu dan pikiran untuk mencurahkan pendapatnya dalam FGD. Jika perlu, sejak awal, dicantumkan dalam undangan mengenai intensif apa yang akan mereka peroleh jika datang dan aktif dalam FGD. Mengenai bentuk dan jumlahnya tentu disesuaikan dengan sumberdaya yang dimiliki peneliti. Umumnya insentif dapat berupa sejumlah uang atau souvenir (cinderamata).

4). Jumlah Peserta

Dalam FGD, jumlah perserta menjadi faktor penting yang harus dipertimbangkan. 
Menurut beberapa literatur tentang FGD jumlah yang ideal adalah 7-11 orang, namun ada juga yang menyarankan jumlah peserta FGD lebih kecil, yaitu 4-7 orang atau 6-8 orang. Terlalu sedikit tidak memberikan variasi yang menarik, dan terlalu banyak akan mengurangi kesempatan masingmasing peserta untuk memberikan sumbangan pikiran yang mendalam. Jumlah peserta dapat dikurangi atau ditambah tergantung dari tujuan penelitian dan fasilitas yang ada [4].

5). Rekruitmen Peserta: Homogen atau Heterogen?

Tekait dengan homogenitas atau heterogenitas peserta FGD, Irwanto mengemukakan prinsip-prinsip sebagai berikut [5]:

1. Pemilihan derajat homogenitas atau heterogenitas peserta harus sesuai dengan tujuan awal diadakannya FGD.

2. Pertimbangan persoalan homogenitas atau heterogenitas ini melibatkan variabel tertentu yang diupayakan untuk heterogen atau homogen. Variabel sosio-ekonomi atau gender boleh heterogen, tetapi peserta itu harus memahami atau mengalami masalah yang didiskusikan. Dalam mempelajari persoalan makro seperti krisis ekonomi atau bencana alam besar, FGD dapat dilakukan dengan peserta yang bervariasi latar belakang sosial ekonominya, tetapi dalam persoalan spesifik, seperti perkosaan atau diskriminasi, sebaiknya peserta lebih homogen.

3. Secara mendasar harus disadari bahwa semakin homogen sebenarnya semakin tidak perlu diadakan FGD karena dengan mewawancarai satu orang saja juga akan diperoleh hasil yang sama atau relatif sama.

4. Semakin heterogen semakin sulit untuk menganalisis hasil FGD karena variasinya terlalu besar.

\section{Homogenitas-heterogenitas}

tergantung dari beberapa aspek. Jika jenis kelamin, status sosial ekonomi, latar belakang agama homogen, tetapi dalam melaksanakan usaha kecil heterogen, maka kelompok tersebut masih dapat berjalan dengan baik dan FGD masih dianggap perlu.

6. Pertimbangan utama dalam menentukan homogenitas-heterogenitas adalah ciri-ciri mana yang harus/boleh/tidak boleh heterogen dan ciriciri mana yang harus/boleh/tidak boleh homogen.

\section{Menyusun Pertanyaan FGD}

Kunci dalam membuat panduan diskusi yang terarah adalah membuat pertanyaanpertanyaan kunci sebagai panduan diskusi. Untuk mengembangkan pertanyaan FGD, lakukan hal-hal berikut:

(2) Baca lagi tujuan penelitian

2. Baca lagi tujuan FGD

(3) Pahami jenis informasi seperti apa yang ingin Anda dapatkan dari FGD

? Bagaimana Anda akan menggunakan informasi tersebut

(3) Tulis pertanyaan umum ke khusus. Sebaiknya jangan lebih dari 5 (lima) pertanyaan inti.

? Rumuskan pertanyaan dalam bahasa yang sederhana dan jelas. Hindari konsep besar yang kabur maknanya.

2] Uji pertanyaan-pertanyaan tersebut pada teman-teman dalam tim Anda.

Berbeda dengan wawancara, dalam FGD 
moderator tidaklah selalu bertanya. Bahkan semestinya tugas moderator bukan bertanya, melainkan mengemukakan suatu permasalahan, kasus, atau kejadian sebagai bahan pancingan diskusi. Dalam prosesnya memang ia sering bertanya, namun itu dilakukan hanya sebagai ketrampilan mengelola diskusi agar tidak didominasi oleh sebagian peserta atau agar diskusi tidak macet [5]

\section{Pelaksanaan FGD}

Keberhasilan pelaksanaan FGD sangat ditentukan oleh kecakapan moderator sebagai "Sang Sutradara". Peran Moderator dalam FGD dapat dilihat dari aktivitas utamanya, baik yang bersifat pokok (secara prosedural pasti dilakukan) maupun yang tentatif (hanya diperlukan jika memang situasi menghendaki demikian). Peranperan tersebut adalah (a) membuka FGD, (b) meminta klarifikasi, (c) melakukan refleksi, (d) memotivasi, (e) probing (penggalian lebih dalam), (f) melakukan blocking dan distribusi (mencegah ada peserta yang dominan dan memberi kesempatan yang lain untuk bersuara), (g) reframing, (h) refokus, (i) melerai perdebatan, (j) memanfaatkan jeda (pause), (k) menegosiasi waktu, dan (l) menutup FGD.

Dalam pelaksanaan FGD, kunci utama agar proses diskusi berjalan baik adalah permulaan. Untuk membuat suasana akrab, cair, namun tetap terarah, tugas awal moderator terkait dengan permulaan diskusi yaitu (1) mengucapkan selamat datang, (2) memaparkan singkat topik yang akan dibahas (overview), (3) membacakan aturan umum diskusi untuk disepakati bersama (atau hal-hal lain yang akan membuat diskusi berjalan mulus), dan (4) mengajukan pertanyaan pertama sebagai panduan awal diskusi. Untuk itu usahakan, baik pertanyaan maupun respon dari jawaban pertama tidak terlalu bertele-tele karena akan menjadi acuan bagi efisisensi proses diskusi tersebut.

Analisis Data dan Penyusunan Laporan FGD Analisis data dan Penulisan Laporan FGD adalah tahap akhir dari kerja keras peneliti. Langkah-langkahnya dapat ditempuh sebagai berikut:

1. Mendengarkan atau melihat kembali rekaman FGD

2. Tulis kembali hasil rekaman secara utuh (membuat transkrip/verbatim)

\section{Baca kembali hasil transkrip}

4. Cari mana masalah-masalah (topik-topik) yang menonjol dan berulang-ulang muncul dalam transkrip, lalu kelompokan menurut masalah atau topik. Kegiatan ini sebaiknya dilakukan oleh dua orang yang berbeda untuk mengurangi "bias" dan "subjektifitas". Pengkategorian bisa juga dilakukan dengan mengikuti Topik-topik dan subtopik dalam Panduan diskusi. Jangan lupa merujuk 
catatan yang dibuat selama proses FGD berlangsung.

Sebelum dilakukan analisis data, dilakukan uji validitas dan uji reliabilitas terhadap instrumen/alat rentang yang digunakan. Dalam penelitian ini, uji validitas atas itemitem kuisioner dilakukan agar data yang diperoleh benar-benar valid serta dapat dipercaya. Dari pengujian validitas instrumen pengukur yang dilakukan dengan memperhatikan nilai communalities sama atau lebih besar dari 0,5 dan factor loading untuk tiap-tiap item pertanyaan sama atau lebih besar dari 0,5.

\section{Pengujian Asumsi Kenormalan}

Menguji apakah model regresi, variabel tak bebas (dependen) mempunyai distribusi normal atau tidak. Model regresi yang baik adalah jika variabel dependen mempunyai distribusi data normal atau mendekati normal. Dari histogram yang disajikan dari output SPSS versi 16 pada lampiran, terlihat bahwa data tingkat kepuasan konsumen mendekati normal. Pada data tersebut terlihat bahwa data tingkat kepuasan mahasiswa mendekati normal, yaitu grafik Normal P-P Plot of Regresion Standardized Residual terlihat bahwa titik-titik menyebar di sekitar garis diagonal dan mengikuti garis normal. Hal ini berarti, asumsi normalitas terpenuhi.

\section{Pengujian Asumsi Bebas}

\section{Heteroskedastisitas}

Deteksi adanya heteroskedastisitas yaitu dengan melihat ada tidaknya pola tertentu pada grafik, di mana sumbu X dan Y yang telah diprediksi dan sumbu Y adalah residual (Y prediksi - Y sesungguhnya) yang telah dibakukan. Bila titiknya menyebar secara tidak berpola (acak) maka tidak terdapat heteroskedastisitas, tapi bila titiknya membentuk pola maka telah terjadi heteroskedastisitas. Hasil uji heteroskedastisitas dari grafik scatterplot pada lampiran, terlihat bahwa titik-titik menyebar secara acak, tidak membentuk pola tertentu yang jelas dan tersebar baik diatas maupun di bawah angka 0 pada sumbu Y. Hal ini berarti tidak terjadi heteroskedastisitas pada model regresi, sehingga model regresi layak untuk digunakan.

\section{Pengujian Autokorelasi}

Dari table summary diperoleh nilai DurbinWatson 1,574. Hal ini menandakan tidak ada autokorelasi antar variabel. Menurut Alqhi Fahri dalam Regresi Berganda, syarat autokorelasi, yaitu : 


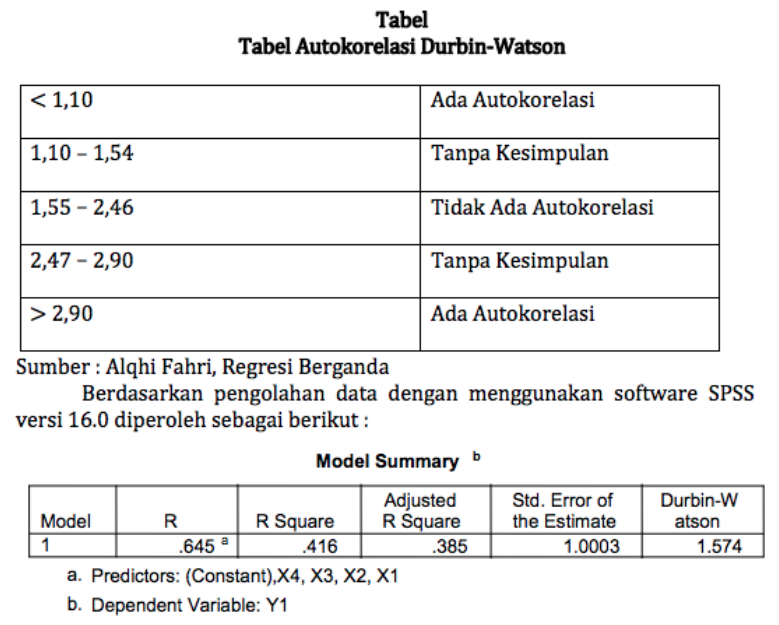

\section{Pengujian ada tidaknya}

\section{Multikolinearitas}

Bertujuan untuk menguji apakah model regresi ditemukan adanya korelasi antar variabel bebas. Model regresi yang baik seharusnya tidak terjadi korelasi di antara variabel bebas. Suatu model regresi yang bebas multikolinearitas adalah yang mempunyai nilai VIF di bawah 10. Dari output yang dikeluarkan SPSS versi 16 terlihat bahwa VIF pada lampiran untuk semua variabel bebas mempunyai angka yang masih lebih kecil dari batasan maksimal terjadi multikolinearitas, sehingga dapat dikatakan model regresinya tidak terkena masalah multikolinearitas. Dari semua variabel X1....X4 menunjukan bahwa nilai Variance Inflation Factor (VIF) memperlihatkan nilai yang $<10$ sehingga dapat dikatakan tidak terjadi multikolinearitas (Dapat di lihat pada tabel Regressi berganda di kolom VIF).

\section{Model Regresi Berganda}

Analisis regresi pada dasarnya adalah studi mengenai ketergantungan variabel dependen dengan satu atau lebih variabel independen, dengan maksud memprediksi rata-rata populasi berdasarkan variabel independen yang diketahui

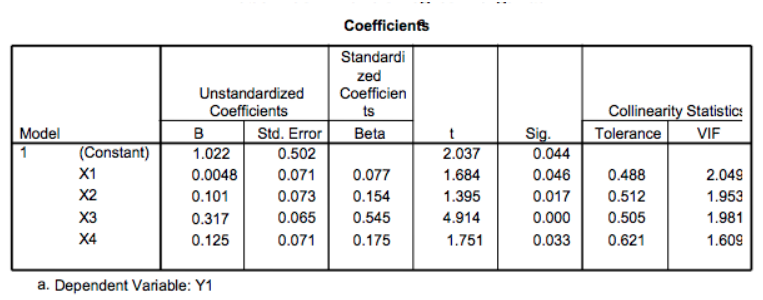

$Y=1,022+0,0048 X 1+0,101 X 2+0,317 X 3$

$+0,125 \times 4$

Keterangan :

$\mathrm{Y}=$ Prestasi Kerja

$\mathrm{X} 1$ = Kebutuhan Fisik

$\mathrm{X} 2$ = Kebutuhan Rasa Aman

X3 = Kebutuhan Sosial

X4 = Kebutuhan Aktualisasi Diri

Berdasarkan persamaan regresi yang diperoleh, dapat dijelaskan mengenai koefisiennya, sebagai berikut :

1. Nilai konstanta (a) menunjukan besarnya Prestasi Kerja $(\mathrm{Y})$ apabila variabel Kebutuhan Fisik (X1), Kebutuhan Rasa Aman (X2), Kebutuhan Sosial (X3), Kebutuhan Aktualisasi Diri (X4) sebesar nol (0) maka besarnya Prestasi Kerja akan bernilai 1,022. Ini berarti bila pegawai pada Dinas Kepemudaan dan Olahraga Kota Tomohon bila dalam proses pelaksanaan pekejaannya tidak didukung oleh ke-4 variabel bebas yang merupakan indikator dari prestasi kerja, maka para pegawai tidak akan termotivasi bahkan kurang semangat dengan pelayanan yang diterimanya sehingga kecil kemungkinan akan meningkat prestasinya.

Koefisien regresi Kebutuhan Fisik (X1) sebesar 0,0048 berarti bahwa jika Faktor 
kebutuhan fisik meningkat atau terjadi perubahan ke arah positif, maka Prestasi Kerja Karyawan berubah secara positif pula. Begitu pula sebaliknya, jika terjadi perubahan kearah negative maka Prestasi Kerja Karyawan (Y) akan berubah secara negative atau menurun.Nilai 0,0048 berarti bahwa jika terjadi perubahan pada variabel kebutuhan fisik sebesar 1 satuan maka Prestasi Kerja Karyawan berubah sebesar 0,0048 artinya apabila pemenuhan kebutuhan fisik pihak pegawai ditingkatkan maka Prestasi Kerja Karyawan (Y) mereka akan naik, begitu pula apabila Kebutuhan Fisik menurun maka Prestasi Kerja Karyawan juga akan turun, dengan asumsi $\mathrm{X} 2, \mathrm{X} 3, \mathrm{X} 4$, tetap.

2. Koefisien regresi Kebutuhan Rasa Aman (X2) sebesar 0,101 artinya jika faktorfaktor motiavasi dalam hal ini kebutuhan rasa aman meningkat atau terjadi perubahan ke arah positif, berarti maka Prestasi kerja karyawan akan berubah secara positif pula. Begitu pula sebaliknya, jika variabel kebutuhan rasa aman terjadi perubahan kearah negative maka Prestasi Kerja (Y) akan berubah secara negative atau menurun.Nilai 0,101 berarti bahwa jika terjadi perubahan pada Kebutuhan rasa aman sebesar 1 satuan maka Prestasi Kerja Karyawan akan berubah sebesar 0,101 artinya apabila varibael kebutuhan rasa aman meningkat Prestasi Kerja Karyawan (Y) akan naik, begitu pula sebaliknya, dengan asumsi X1, X3, X4, tetap.

3. Koefisien regresi Kebutuhan Sosial (X3) sebesar 0,317. Nilai 0,317 berarti bahwa jika terjadi perubahan pada variabel Kebutuhan Sosial sebesar 1 satuan maka Prestasi Kerja akan berubah sebesar 0,317 artinya apabila kebutuhan sosial pegawaidiperhatikan di lingkungan pekerjaan maka Prestasi Kerja (Y) akan naik, begitu pula apabila Kebutuhan Sosial menurun atau tidak terakomodiir maka
Prestasi Kerja pegawai juga akan turun, dengan asumsi X1, X2, X4, tetap.

4. Koefisien regresi variabel Kebutuhan Aktualisasi Diri (X4) sebesar 0,125 . Nilai 0,125 berarti bahwa jika terjadi perubahan pada kebutuhan aktualisasi diri sebesar 1 satuan maka Prestasi Kerja pegawai akan berubah sebesar 1,826 artinya apabila Kebutuhan aktualisasi diri pegawai lebih diperhatikan maka Prestasi Kerja pegawai (Y) akan naik, begitu pula sebaliknya, dengan asumsi X1, X2, X3,dan X4 tetap.

Uji Kelayakan (Validitas Model)

Koefisien korelasi (Multiple R) secara menyeluruh sebesar 0,745 atau 74,5 \% yang artinya hubungan antara Kebutuhan Fisik (X1), Kebutuhan Rasa Aman(X2), Kebutuhan Sosial (X3), dan Kebutuhan Aktualisasi Diri (X4), sebagai variabel bebas dengan Prestasi Kerja pegawai (Y)sebagai variabel terikat adalah positif dan cukup kuat. Ini berarti apabila pihak pimpinan Dinas Kepemudaan dan Olahraga Kota Tomohon memperhatikan Prestasi Kerja pegawaiy ang dijabarkan ke dalam 4 variabel bebas, maka Prestasi Kerja pegawaiakan meningkat. Sedangkan nilai koefisien determinasi (R2) adalah 0,616. Ini berarti sebesar 61,6\% proporsi keragaman Prestasi Kerja pegawai(Y) yang dapat dijelaskan oleh $\mathrm{X} 1$, $\mathrm{X} 2$, X3, dan X4, sedangkan 38,4\% lainnya dijelaskan oleh variabel lain di luar ke 4 variabel bebas tersebut yang tidak diteliti dalam penelitian ini.

Jadi, berdasarkan koefisien determinasi dapat diketahui bahwa Variabel X1, X2, X3, $\mathrm{X} 4$ mempunyai pengaruh yang nyata/signifikan terhadap Prestasi Kerja pegawai pada Dinas Kepemudaan dan Olahraga Kota Tomohon. Dan berdasarkan uji kelayakan (validitas model) dengan menggunakan nilai $\mathrm{F}$ hitung yang diperoleh sebesar 13,386 dengan signikansi 0,000 
lebih kecil daripada 0,05 maka dapat dikatakan bahwa model persamaan tersebut layak digunakan dan secara keseluruhan variabelvariabel bebasnya mempunyai pengaruh yang signifikan(berarti) terhadap Prestasi Kerja pegawai.

\section{KESIMPULAN}

Kesimpuulan yang didapatkan adalah:

1. Prestasi Kerja yang divariabelkan dalam bentuk Kebutuhan Fisik (X1), Kebutuhan Rasa Aman (X2), Kebutuhan Sosial (X3), dan Kebutuhan Aktualisasi Diri (X4), mempunyai pengaruh terhadap Prestasi kerja karyawan, ini dibuktikan dengan Uji F (F ratio), di mana ke 4 variabel bebas tersebut berpengaruh 13,386\% terhadap Prestasi kerja karyawan.

2. Pengaruh variabelvariabel bebas yaitu Kebutuhan Fisik (X1), Kebutuhan Rasa Aman (X2), Kebutuhan Sosial (X3), dan Kebutuhan Aktualisasi Diri (X4) terhadapvariabel terikatnya yaitu Prestasi Kerja Pegawai (Y). Diantara variabelX1 sampai dengan X4di atas, variabel Kebutuhan Sosial (X3) dominan mempengaruhi Prestasi kerja karyawan dengan nilai t hitung sebesar 4,914 dan signifikan 0,000.

3. Berdasarkan nilai koefisien regresi dari variabel-variabel bebas yang diperoleh, secara keseluruhan pengaruhnya terhadap Prestasi Kerja Pegawai (Y) semuanya menunjukkan nilai yang positif (signifikan), namun Kebutuhan Sosialyang paling besar pengaruhnya.

Hal ini menunjukkan bahwa sebagian Pegawai pada Dinas Kepemudaan dan Olahraga Kota Tomohon, cenderung memilih variabel Kebutuhan Sosial yang paling menyentuh dan memotivasi semangat bekerja mereka, karena merupakan dorongan yang sangat berarti apabila karayawan bekerja dengan kondisi kerja yang baik karena interaksi sosial sesama pegawai bahkan dengan atasan berjalan dengan baik, dan itu dirasakan besar sekali pengaruhnya buat diri pegawai. Apabila beberapa variabel motivasi tersebut lebih diperhatikan oleh pihak pimpinan dan manajemen Dinas Kepemudaan dan Olahraga Kota Tomohon, akan meningkatkan prestasi kerja pegawai sebagai bagian dari organisasi di Dinas Kepemudaan dan Olahraga Kota Tomohon, yang mendorong semangat bekerja mereka mereka di lingkungan pekerjaannya tersebut.

\section{REFERENSI}

[1] I. Setiawan dan I. Ghozali, "Akuntansi Keprilakuan: Konsep dan Kajian Empiris Perilaku Akuntan," 2006.

[2] Vroom Victor H. "Work and Motivation," New York : John Wiley \& Sons, 1964.

[3] Krueger \& Casey, "A Practical Guide for Applied Research," California: Sage Publications Publish, 2000.

[4] Koentjaraningrat, "Pengantar Antropologi," Jakarta: PT Rineka Cipta, 2005.

[5] Irwanto, "Keanekaragaman Fauna pada Habitat Mangrove,"Yogyakart, 2006 